\title{
ANALISA KOMPARATIF USAHA TANI PADI ORGANIK DAN PADI ANORGANIK (STUDI KASUS DI KELOMPOK TANI SUMBER JAYA DESA RAJEKWESI KECAMATAN KENDIT KABUPATEN SITUBONDO)
}

\author{
Sutikno \\ Balai Penyuluhan Pertanian, Dinas Tanaman Pangan, Holtikulutra, dan Perkebunan Situbondo \\ Email Korespondensi : sutiknoppl17@gmail.com
}

\begin{abstract}
Abstrak
Penelitian ini bertujuan untuk (1) menganalisis penerimaan, (2) menganalisis pendapatan dan (3) menganalisis efisiensi. Penelitian ini dilaksanakan di Desa Rajekwesi Kecamatan Kendit. Pengumpulan data menggunakan metode wawancara langsung dan dokumentasi. Data yang diperoleh dianalisis secara deskriptif dan menggunakan uji independent sampel $\mathrm{t}$ test. Hasil penelitian menunjukkan bahwa terdapat perbedaan yang signifikan antara usahatani padi organik dan padi anorganik dalam hal penerimaan, pendapatan dan efisiensi usaha tani.
\end{abstract}

Kata Kunci : penerimaan, pendapatan, efisiensi.

\begin{abstract}
This study aims to (1) analyze revenue, (2) analyze income and (3) analyze efficiency. This research was carried out in Rajekwesi Village, Kendit District. Data collection using the method of direct interviews and documentation. The data obtained were analyzed descriptively and using the independent sample $t$ test. The results showed that there were significant differences between organic and inorganic rice farming in terms of revenue, income and efficiency of farming.
\end{abstract}

Keywords: revenue, income, efficiency

\section{PENDAHULUAN}

Seiring dengan bertambahnya jumlah penduduk, Indonesia sebagai negara agraris telah berupaya meningkatkan hasil produksi beras untuk memenuhi kebutuhan masyarakat. Dalam hal ini pemerintah telah melakukan upaya-upaya untuk dapat memenuhi kebutuhan pangan serta menekan harga bahan pangan menjadi lebih terjangkau. Salah satunya adalah kabijakan revolusi hijau yang dimulai sejak tahun 1960an. Namun upaya tersebut dinilai telah menimbulkan dampak negatif bagi ekosistem dan kesehatan sehingga perlu upaya mengembalikan struktur tanah.

Salah satu cara untuk mencapai pertanian yang berkelanjutan maka diperlukan adanya teknologi yang ramah lingkungan untuk menghasilkan bahan makanan yang aman bebas dari bahan-bahan kimia berbahaya dan beracun, dengan menerapkan teknologi yang murah dan mudah bagi petani seperti penggunaan pupuk organik, mikro organisme lokal dan pestisida nabati

Kesadaran penduduk untuk menjaga kualitas kesehatan dengan mengkonsumsi padi organik merupakan peluang bagi petani untuk meningkatkan kualitas pertanian mereka dengan mengintensifkan pertanian organik karena selain lebih diminati tetapi juga memiliki harga yang lebih tinggi. Kurangnya pengetahuan petani terhadap pertanian organik membuat sebagian kecil petani menangkap adanya peluang tersebut, dan 
sebagian besar petani lainnya masih enggan untuk mengoptimalkan pertanian organik mereka sehingga kemajuan pertanian organik tidak berjalan dengan baik.

Berdasarkan dua sistem budidaya tersebut di atas maka penelitian dilakukan untuk mengetahui adakah perbedaan penerimaan, pendapatan, dan perbedaan efisiensi usahatani padi organik dan padi anorganik di kelompok tani Sumber Jaya Desa Rajekwesi Kecamatan Kendit Kabupaten Situbondo.

\section{METODE PENELITIAN}

Untuk membuktikan hipotesa adanya perbedaan pendapatan dan efisiensi (R/C rasio), penelitian ini menggunakan Deskriptif Kuantitatif dengan bantuan perhitungan menggunakan microsoft office excel. Dari perbedaan Deskriptif Kuantitatif, dianalisis secara statistik menggunakan uji beda (Independent sample $t$ test) dengan bantuan program SPSS ver 15

Penelitian ini bertempat di kelompok tani Sumber Jaya desa Rajekwesi kecamatan Kendit kabupaten Situbondo provinsi Jawa Timur, dengan pertimbangan pertama bahwa desa Rajekwesi memiliki kelompok tani berprestasi tingkat kabupaten bidang pertanian. Semenjak tahun 2017 mulai melakukan penanaman padi organik hingga saat ini. Kelompok tani desa ini merupakan pilot project pengembangan pertanian organik yang dicanangkan Bupati Situbondo, selain karena potensi SDM yang mumpuni juga karena SDA yang cocok untuk pengembangan kawasan padi organik di kabupaten Situbondo. Pertimbangan kedua yaitu lokasi desa Rajekwesi dengan rumah peneliti tidak terlalu jauh, sehingga pemilihan lokasi dilakukan secara sengaja (purposive). Waktu penelitian yaitu bulan sejak Nopember 2018 sampai dengan bulan Januari 2019.

Pemilihan petani responden dilakukan secara purposive menggunakan tehnik sampling non-Random (non probability sampling) yaitu purposive sampling. Petani dibagi menjadi 2 kelompok, yaitu kelompok pembudidaya padi organik 26 orang dan pembudidaya padi anorganik 26 responden, sehingga total responden 52 orang.

Penelitian ini merupakan terdiri dari dua tahap. Tahap pertama yaitu wawancara, pengamatan lapang, pengolahan dan analisis data. Tahap kedua adalah pengambilan data dari literatur yang diperoleh dari instansi terkait seperti Dinas Tanaman Pangan Hortikultura kabupaten Situbondo, Balai Penyuluhan Pertanian Panarukan, Penyuluh Pertanian Lapang desa Rajekwesi, Kantor Desa maupun Media online.

Metode yang diterapkan selaras yaitu deskriptif kuantitatif. Analisis yang dilakukan adalah penerimaan, pendapatan dan efisiensi (R/C rasio) dan disajikan dalam bentuk tabulasi dan diuraikan secara deskriptif.

Selanjutnya untuk membuktikan kebenaran hipotesis analisis penerimaan dan pendapatan tersebut maka dilakukan uji t :

$$
t=\frac{x_{1}-x_{2}}{\sqrt{\left(\frac{\left(n_{1}-1\right) S^{2}{ }_{1}+\left(n_{2}-2\right) S^{2}{ }_{2}}{n_{1}+n_{2}-2}\right)\left(\frac{1}{n_{1}}+\frac{1}{n_{2}}\right)}}
$$

Dari perhitungan statistik diatas maka sampel yang dibandingkan dengan nilai t pada tabel akan diambil keputusan :

1. Jika Sig. (2-tailed) $>0,05$ atau t hitung $<\mathrm{t}$ tabel, maka HO diterima, Ha ditolak artinya non signifikan atau tidak terdapat perbedaan nyata antara penerimaan padi organik dengan produksi padi anorganik.

2. Jika Sig. (2-tailed) < 0,05 atau t hitung $>\mathrm{t}$ tabel, maka HO ditolak, Ha diterima, artinya signifikan atau terdapat perbedaan nyata antara produksi padi organik dengan produksi padi anorganik. 
Pembuktian hipotesis ketiga yaitu membandingkan efisiensi usahatani padi organik dan padi anorganik, dihitung dengan rumus sebagai berikut :

$$
\mathrm{E}=\frac{\mathrm{TR}}{\mathrm{TC}}
$$

Keterangan :

$\mathrm{E}=$ Nilai efisiensi

$\mathrm{TR}=$ Total Penerimaan

$\mathrm{TC}=$ Total biaya

Sedangkan untuk menguji kebenaran hipotesa maka data efisiensi ditabulasi menggunakan Microsoft Excel. Selanjutnya untuk membuktikan kebenaran hipotesis tersebut maka dilakukan uji t.

\section{HASIL DAN PEMBAHASAN}

\section{Gambaran Umum Lokasi Penelitian}

Desa Rajekwesi memiliki luas areal wilayah seluas 18,22 $\mathrm{Km}^{2}$ atau 182,2 Ha, tinggi tempat $104 \mathrm{~m} \mathrm{dpl}$, Suhu rata-rata tahunan sekitar 25-33 ${ }^{\circ} \mathrm{C}$. Memiliki jarak $13 \mathrm{Km}$ ke kantor Kecamatan Kendit dan 25 Km ke Ibukota Kabupaten Situbondo.

Desa Rajekwesi dibatasi wilayah sebelah utara adalah desa Kukusan kec. Kendit, sebelah Selatan kabupaten Bondowoso, sebelah barat desa Sumber anyar kec. Mlandingan, dan sebelah timur desa Tambak ukir kec. Kendit.

\section{Pendidikan}

Sebagian besar petani desa Rajekwesi berpendidikan rendah. Hal ini seperti yang ditunjukkan pada tabel 1 bahwa dari 26 responden petani padi organik sebanyak 16 orang $(57,7 \%)$ tidak sekolah, lulus SD 5 orang $(19,2 \%)$,lulus SMP 3 orang $(11,5 \%)$ dan lulus SMA/SMK 3 orang (11,5\%).

Tabel 1. Pendidikan yang ditamatkan petani pengguna padi organik dan

\begin{tabular}{ccccc}
\hline \multirow{2}{*}{ Pendidikan } & \multicolumn{2}{c}{ Padi Organik } & \multicolumn{2}{c}{ Padi Anorganik } \\
\cline { 2 - 5 } & Petani (org) & $(\%)$ & Petani (org) & $(\%)$ \\
\hline Tidak sekolah & 15 & 57,7 & 13 & 50 \\
Lulus SD & 5 & 19,2 & 7 & 26,9 \\
Lulus SMP & 3 & 11,5 & 5 & 11,5 \\
Lulus SMA & 3 & 11,5 & 1 & 3,8 \\
\hline Total & 26 & 100 & 26 & 100 \\
\hline
\end{tabular}

Sedanglan petani responden padi anorganik sebanyak 26 orang terdiri dari 13 orang tidak sekolah (50\%), 7 orang lulus SD $(26,9 \%), 5$ orang lulus SMP $(11,5 \%)$ dan lulus SMA/SMK sebanyak 1 orang $(3,8 \%)$. 


\section{Pengalaman bertani}

Berikut pengalaman bertani responden kelompok tani Sumber jaya di desa Rajekwesi kecamatan Kendit kabupaten Situbondo.

Tabel 2. Pengalaman bertani

\begin{tabular}{ccccc}
\hline \multirow{2}{*}{$\begin{array}{c}\text { Pengalaman bertani } \\
\text { (tahun) }\end{array}$} & \multicolumn{2}{c}{ Padi Organik } & \multicolumn{2}{c}{ Padi Anorganik } \\
\cline { 2 - 5 } & Petani (org) & $(\%)$ & Petani (org) & $(\%)$ \\
\hline 1 & 6 & 23,07 & - & - \\
2 & 6 & 23,07 & - & - \\
3 & 14 & 53,84 & - & - \\
6 & - & - & 2 & 7,69 \\
7 & - & - & 8 & 30,76 \\
8 & - & - & 6 & 23,07 \\
9 & - & - & 3 & 11,53 \\
$>10$ & - & - & 7 & 26,92 \\
\hline Total & 26 & 100 & 26 & 100 \\
\hline
\end{tabular}

Berdasarkan data, petani organik memiliki persentase tertinggi pada mereka yang memiliki pengalaman bertani 3 tahun. Pada kriteria ini petani masih sangat terbuka terhadap inovasi. Mereka memiliki kecenderungan yang cukup tinggi untuk mencoba halhal baru.

Sebaliknya, petani yang memiliki pengalaman bertani lama lebih sulit menerima inovasi karena mereka memiliki pengetahuan bertani yang lebih lama sehingga lebih tertutup terhadap perubahan.

\section{Umur responden}

Tabel 3. Umur responden

\begin{tabular}{ccccc}
\hline Umur & \multicolumn{2}{c}{ Padi Organik } & \multicolumn{2}{c}{ Padi Anorganik } \\
\cline { 2 - 5 } (tahun) & Petani (org) & $(\%)$ & Petani (org) & $(\%)$ \\
\hline $30-40$ & 4 & 15,38 & 6 & 23,07 \\
$41-49$ & 7 & 26,92 & 7 & 26,92 \\
$>50$ & 15 & 57,69 & 13 & 50 \\
\hline Total & 26 & 100 & 26 & 100 \\
\hline
\end{tabular}

Umur berkorelasi positif dengan serapan teknologi karena semakin muda usia petani maka semakin mudah untuk menerima suatu perubahan atas kemajuan sarana informasi teknologi, sehingga akan meningkatkan produktivitas usaha taninya.

Namun, tabel 3 menunjukkan kenyataan yang sebaliknya. 57,69 \% petani padi organik dan $50 \%$ petani padi anorganik berusia $>50$ tahun. hal itu terjadi karena generasi muda lebih memilih untuk menjadi buruh atau karyawan pabrik daripada menjadi petani.

\section{Luas lahan}

Luas lahan ditunjukkan pada tabel dibawah, dimana untuk responden pengguna padi organik yang menggarap sawah antara 1000-3000 $\mathrm{M}^{2}$ sebanyak 7 petani $(26,92 \%)$, responden dengan luasan 3001-4999 $\mathrm{M}^{2}$ sebanyak 7 orang $(26,92 \%)$, responden dengan luasan 5000-9999 $\mathrm{M}^{2}$ sebanyak 11 orang (42,30\%), dan yang memiliki luas lahan lebih dari 1 Ha sebanyak 1 orang (3,84\%). 
Tabel 4. Luas lahan responden padi

\begin{tabular}{lllll}
\hline \multirow{2}{*}{ Luas (M2) } & Padi Organik & \multicolumn{3}{c}{ Padi Anorganik } \\
\cline { 2 - 5 } & Petani (org) & $(\%)$ & Petani (org) & $(\%)$ \\
\hline $1000-3000$ & 7 & 26,92 & 7 & 26,92 \\
$3001-4999$ & 7 & 26,92 & 7 & 26,92 \\
$5000-9999$ & 11 & 42,30 & 11 & 42,30 \\
$>10000$ & 1 & 3,84 & 1 & 3,84 \\
\hline Total & 26 & 100 & 26 & 100 \\
\hline
\end{tabular}

Sedangkan responden yang menggunakan padi anorganik dengan luas lahan antara 1000-3000 M² sebanyak 7 petani (26,92\%), responden dengan luasan 3001-4999 $\mathrm{M}^{2}$ sebanyak 7 orang $(26,92 \%)$, responden dengan luasan 5000-9999 $\mathrm{M}^{2}$ sebanyak 11 orang $(42,30 \%)$, dan responden yang memiliki luas lahan lebih dari 1 Ha sebanyak 1 orang $(3,84 \%)$.

\section{Penerimaan Usahatani}

Penerimaan adalah hasil perkalian dari jumlah produksi total dengan harga produk, berupa gabah kering panen atau GKP selama 1 musim tanam per hektar yang telah dikonversi menjadi beras. Sementara untuk harga beras padi organik Rp. 13.000,-/kg sedangkan padi anorganik sebesar Rp.9.000,-/kg.

Berikut produksi Usahatani Padi organik dan anorganik disajikan pada tabel di bawah ini :

Tabel 5. Produksi padi organik dan anorganik, di desa Rajekwesi kecamatan Kendit kabupaten Situbondo tahun 2018.

\begin{tabular}{cccc}
\hline \multirow{2}{*}{ Perlakuan } & \multicolumn{3}{c}{ Produksi beras rata-rata $(\mathrm{Kg} / \mathrm{Ha})$} \\
\cline { 2 - 4 } & Minimum & Maksimum & Rata-rata \\
\hline Padi organik & $1.988,1$ & $3.134,5$ & $2.621,2$ \\
Padi anorganik & $1.492,6$ & $2.540,1$ & 2.067 \\
\hline
\end{tabular}

Dapat dilihat bahwa produksi beras hasil organik minimum 1988,1 kg/Ha maksimum $3134,5 \mathrm{~kg} / \mathrm{Ha}$ dan rata-rata $2621,2 \mathrm{~kg} / \mathrm{Ha}$ sedangkan produksi beras anorganik minimum 1492,6 kg/Ha, maksimum 2540,1 kg/Ha dan rata-rata $2067 \mathrm{~kg} / \mathrm{Ha}$.

Dari uraian di atas dapat dikatakan bahwa rata- rata produksi usahatani padi sawah dengan budidaya organik lebih tinggi dari anorganik.

Dari data produksi diatas dapat diketahui penerimaan usahatani padi organik dan anorganik, disajikan pada tabel di bawah ini :

Tabel 6. Penerimaan Padi organik dan anorganik, di desa Rajekwesi kecamatan Kendit kabupaten Situbondo tahun 2018.

\begin{tabular}{cccc}
\hline \multirow{2}{*}{ Perlakuan } & \multicolumn{3}{c}{ Penerimaan beras (Rp/Ha) } \\
\cline { 2 - 4 } & Minimum & Maksimum & Rata-rata \\
\hline Padi organik & 25.845 .867 & 40.747 .988 & 34.076 .222 \\
Padi anorganik & 13.433 .403 & 22.861 .209 & 18.602 .623 \\
\hline
\end{tabular}

Dari tabel di atas dapat dilihat bahwa padi organik memiliki penerimaan minimum Rp. 25.845.867 /Ha,-. Hal ini terjadi karena beras hasil produksi padi organik sebesar $1.988,1 \mathrm{Kg} / \mathrm{Ha}$ dikali harga Rp. 13.000/Kg,-. Penerimaan maksimum sebesar Rp. 40.747.988,-. Hal ini disebabkan karena produktivitas padi sebesar $3.134,5 \mathrm{Kg} / \mathrm{Ha}$ dikali dengan harga jual per Kg Rp. 13.000,-. Untuk rata-rata penerimaan beras padi organik sebesar Rp. 34.076.222,- dengan produksi rata-rata 2.621,2 Kg GKS dikali dengan harga jual per Kg sebesar Rp.13.000,- 
Sedangkan penerimaan dengan menggunakan padi anorganik minimum Rp. 13.433.403,-. Hal ini terjadi karena beras hasil produksi padi anorganik 1.492,6 Kg dikali dengan harga per Kg Rp. 9000,-. Penerimaan maksimum beras anorganik Rp. 22.861.209,Hal ini disebabkan karena beras hasil produksi padi anorganik sebesar 2.540,1 Kg dikali dengan harga jual beras per Kg Rp. 9000 dan untuk penerimaan rata-rata Rp. 18.602.623,dengan produksi rata-rata $2.067 \mathrm{Kg}$ beras dikali dengan harga jual per $\mathrm{Kg}$ sebesar Rp.9000,-

Sehingga kesimpulannya, terdapat perbedaan rata-rata penerimaan padi organik dan anorganik. pembuktiannya apakah ada perbedaan yang nyata atau signifikan, maka peneliti menggunakan uji independent te-test sebagai berikut :

Tabel 7. Uji T untuk penerimaan usahatani padi organik dan anorganik, di desa Rajekwesi kecamatan Kendit kabupaten Situbondo tahun 2018

\begin{tabular}{|c|c|c|c|c|c|}
\hline Perlakuan & $\begin{array}{c}\text { Rata-rata } \\
\text { Penerimaan } \\
\text { Beras }(\mathrm{Rp} / \mathrm{Ha})\end{array}$ & $\begin{array}{l}\text { Nilai t } \\
\text { hitung }\end{array}$ & $\begin{array}{l}\text { Nilai t } \\
\text { tabel }\end{array}$ & $\begin{array}{l}\text { Sig.(2- } \\
\text { tailet) }\end{array}$ & $\begin{array}{c}\text { Tingkat kepercayaan } \\
95 \%(\alpha)\end{array}$ \\
\hline $\begin{array}{c}\text { Padi organik } \\
\text { Padi anorganik }\end{array}$ & $\begin{array}{l}34.076 .222 \\
18.602 .623\end{array}$ & 19,988 & 2,074 & 0,00 & 0,05 \\
\hline
\end{tabular}

Tabel diatas menunjukkan perbedaan penerimaan usahatani padi sawah organik dengan padi anorganik, dimana nilai Sig. (2-tailed) yaitu 0,00 $<0,05$ atau $t$ hitung $>\mathrm{t}$ tabel yaitu 19,988 $>2,074$, maka HO ditolak dan Ha diterima artinya terdapat perbedaan yang signifikan antara penerimaan padi organik dengan penerimaan padi anorganik pada tingkat kepercayaan 95\%.

Penerimaan usahatani padi organik melebihi usahatani padi anorganik, hal ini terjadi karena rata-rata produksi padi organik jauh lebih tinggi yaitu sebesar $(2621,2$ $\mathrm{Kg} / \mathrm{Ha}$ ) dibandingkan dengan padi anorganik yang sebesar (2067 Kg/Ha). Demikian pula dengan harga jual beras per kilogram, karena usahatani yang menggunakan padi organik lebih ramah lingkungan, sehingga memiliki nilai tawar yang lebih tinggi.

Masyarakat sudah mulai sadar akan bahaya dari residu bahan kimia yang ada pada bahan pangan. Sehingga masyarakat lebih memilih/beralih mengkonsumsi padi organik walaupun dengan harga hampir dua kali lipat. Bahan kimia yang digunakan untuk mengendalikan hama, pengairan yang tercampur bahan kima tentu berpengaruh pada tanaman padi anorganik juga berbahaya bagi kesehatan manusia. Jika digunakan dalam jangka panjang, beresiko menimbulkan beberapa masalah kesehatan seperti gangguan reproduksi, gangguan kehamilan dan janin, penyakit parkinson, kanker dan masih banyak lagi efek yang ditimbulkan.

\section{Pendapatan usahatani}

Adalah nilai selisih antara total penerimaan dengan total biaya.. Sedangkan biaya total usahatani padi sawah baik organik maupun anorganik dapat dilihat pada tabel di bawah ini :

Tabel 8. Biaya usahatani padi organik dan padi anorganik, di desa Rajekwesi kecamatan Kendit kabupaten Situbondo tahun 2018

\begin{tabular}{cccc}
\hline \multirow{2}{*}{ Perlakuan } & \multicolumn{3}{c}{ Biaya (Rp/Ha) } \\
\cline { 2 - 4 } & Minimum & Maksimum & Rata-rata \\
\hline Padi organik & $8.800 .825,-$ & $20.715 .000,-$ & 13.136 .679 \\
Padi anorganik & $6.458 .562,-$ & $14.401 .250,-$ & $10.379 .739,-$ \\
\hline
\end{tabular}


Dari uraian di atas dapat dikatakan bahwa biaya usahatani padi organik rata-rata lebih tinggi daripada biaya usahatani padi anorganik dengan margin angka yang tidak terlalu jauh.

Sehingga dapat diketahui pendapatan usahatani padi sawah baik organik maupun anorganik disajikan pada tabel di bawah ini :

Tabel 9. Rata rata pendapatan per hektar usahatani padi organik dan padi anorganik, di desa Rajekwesi kecamatan Kendit kabupaten Situbondo tahun 2018

\begin{tabular}{cccc}
\hline \multirow{2}{*}{ Perlakuan } & \multicolumn{3}{c}{ Rata-rata TR-TC } \\
\cline { 2 - 4 } & Penerimaan rata- & Biaya & Pendapatan rata- \\
& rata & 13.136 .679 & rata \\
\hline Padi organik & 34.076 .222 & 10.379 .739 & 20.939 .543 \\
Padi anorganik & 18.602 .623 & 8.222 .884 \\
\hline
\end{tabular}

Berdasarkan tabel di atas dapat dilihat bahwa pendapatan padi organik rata-rata Rp 20.939.543,-. Dan pendapatan rata-rata padi anorganik Rp 8.222.884,--

Dari uraian di atas dapat disimpulkan bahwa usahatani padi organik lebih menguntungkan daripada usahatani padi anorganik. Sehingga disimpulkan bahwa ratarata pendapatan padi organiklebih tinggi dari padi anorganik. Untuk membuktikan apakah ada perbedaan yang nyata, maka menggunakan uji independent te-test sebagai berikut:

Tabel 10. Perbedaan pendapatan usahatani padi organik dan padi anorganik menggunakan uji T, di Desa Rajekwesi Kecamatan Kendit Kabupaten Situbondo Tahun 2018

\begin{tabular}{cccccc}
\hline Perlakuan & $\begin{array}{c}\text { Rata-rata } \\
\text { Pendapatan } \\
\text { Beras (Rp/Ha) }\end{array}$ & $\begin{array}{c}\text { Nilai t } \\
\text { hitung }\end{array}$ & $\begin{array}{c}\text { Nilai t } \\
\text { tabel }\end{array}$ & $\begin{array}{c}\text { Sig. }(2- \\
\text { tailet })\end{array}$ & $\begin{array}{c}\text { Tingkat kepercayaan } \\
95 \%(\alpha)\end{array}$ \\
\hline $\begin{array}{c}\text { Padi organik } \\
\text { Padi anorganik }\end{array}$ & $\begin{array}{c}20.939 .543,- \\
8.222 .884,-\end{array}$ & 16,808 & 2,074 & 0,00 & 0,05 \\
\hline
\end{tabular}

Tabel di atas menunjukkan nilai Sig. (2-tailed) yaitu 0,000 $<0,05$ atau $\mathrm{t}$ tabel $>\mathrm{t}$ hitung yaitu16,808 > 2,074 maka H0 ditolak dan Ha diterima artinya terdapat perbedaan yang signifikan antara pendapatan padi organik dengan pendapatan padi anorganik pada tingkat kepercayaan 95\%.

Usahatani padi organik mempunyai pendapatan lebih tinggi di bandingkan dengan usahatani padi anorganik karena nilai jual beras lebih tinggi walaupun inputnya lebih tinggi tetapi harga jual dan produksinya dapat menutupi biaya produksinya. Penggunaan pestisida dalam proses produksi pertanian juga mengakibatkan timbulnya residu pestisida pada hasil pertanian. Residu pada padi anorganik dapat terjadi pada tanaman (daun, buah, cabang, akar, kulit \& sebagainya) tanah dan air yang selanjutnya dapat membahayakan kesehatan masyarakat.

Kemudian karena ketersediaan padi organik ini dalam jumlah terbatas dan permintaan yang banyak jelas akan berdampak pada harga. Sesuai hukum ekonomi bahwa semakin banyak penawaran sedangkan ketersediaan sedikit harga akan naik.

Kesimpulan yang ditunjukkan bahwa terdapat perbedaan yang signifikan pendapatan usahatani padi organik dan padi anorganik. Budidaya padi organik lebih memberikan pendapatan yang tinggi dibandingkan dengan budidaya padi anorganik. 


\section{Efisiensi Usahatani}

Tabel 11. Efisiensi usahatani per hektar padi organik dan padi anorganik, di Desa Rajekwesi Kecamatan Kendit.

\begin{tabular}{cccc}
\hline Perlakuan & $\begin{array}{c}\text { Penerimaan } \\
(\mathrm{Rp})\end{array}$ & Biaya ( Rp ) & R/C \\
\hline Padi organik & 34.076 .222 & 13.136 .679 & 2,59 \\
Padi anorganik & 18.602 .623 & 10.379 .739 & 1,79 \\
\hline
\end{tabular}

$\mathrm{R} / \mathrm{C}$ rasio dapat dilihat dari hasil pembagian antara total penerimaan dengan total biaya. Dari tabel di atas dapat diketahui bahwa nilai $\mathrm{R} / \mathrm{C}$ rasio usahatani padi organik 2,59 sedangkan nilai $\mathrm{R} / \mathrm{C}$ rasio usahatani padi anorganik 1,79 , sehingga dapat dikatakan bahwa budidaya padi organik maupun anorganik tersebut sama-sama efisien, tapi padi organik lebih efisien daripada padi anorganik. Artinya dapat disimpulkan bahwa usahatani padi organik lebih menguntungkan (secara finansial) daripada padi anorganik. Untuk membuktikan apakah ada perbedaan yang nyata, menggunakan uji independent te-test di bawah ini :

Tabel 12. Perbedaan efisiensi usahatani padi organik dan padi anorganik, di Desa Rajekwesi Kecamatan Kendit Kabupaten Situbondo Tahun 2018

\begin{tabular}{|c|c|c|c|c|c|}
\hline Perlakuan & $\mathrm{R} / \mathrm{C}$ & $\begin{array}{l}\text { Nilai t } \\
\text { hitung }\end{array}$ & $\begin{array}{l}\text { Nilait } \\
\text { tabel }\end{array}$ & Sig.(2-tailet) & $\begin{array}{c}\text { Tingkat kepercayaan } 95 \% \\
(\alpha)\end{array}$ \\
\hline $\begin{array}{c}\text { Organik } \\
\text { Anorganik }\end{array}$ & $\begin{array}{l}2,59 \\
1,79\end{array}$ & 5,371 & 2,074 & 0,000 & 0,05 \\
\hline
\end{tabular}

Diketahui dari tabel di atas ada perbedaan efisiensi usahatani pada kegiatan padi organik dan padi anorganik, nilai Sig. (2-tailed) yaitu 0,000 $<0,05$ atau $t$ tabel $>t$ hitung 5,371 > 2,074 maka H0 ditolak dan Ha diterima pada tingkat kepercayaan 95\%.

Analisa efisiensi atau R/C atau Return Cost Ratio digunakan untuk menggambarkan seberapa besar adanya efisiensi biaya,. Semakin besar nilai $\mathrm{R} / \mathrm{C}$ yang diperoleh maka usaha semakin efisien. Perhitungan R/C juga dihitung dari biaya total maupun biaya tunai dengan cara membagi penerimaan total terhadap biaya total. Melihat keadaan diatas dapat diketahui bahwa keputusan petani untuk berusaha tani padi organik sudah tepat.

\section{KESIMPULAN}

Kesimpulan dari keseluruhan hasil penelitian yaitu :

1) Penerimaan Usahatani padi organik lebih tinggi dibandingkan usahatani padi anorganik.

2) Pendapatan Usahatani padi organik lebih tinggi dibandingkan usahatani padi anorganik.

3) Usahatani padi organik mempunyai tingkat efisiensi yang lebih tinggi dibandingkan dengan padi anorganik. 


\section{REFERENSI}

Harini, R., Bowo Susilo dan Emilya Nurjani. 2015. Geographic Information System-Based Spatial Analysis of Agriculture Land Suitability in Yogyakarta. Indonesian Journal of Geography. 47(2), 171-179.

Ningtyas, 2011. Analisis Usahatani Padi Konvensional dan Padi System of Rice Intensification (STI) Organik. [Skripsi]. Bogor (ID) : Fakultas Ekonomi dan Manajemen, Institut Pertanian Bogor. 